\title{
Suitability of Some Selected Clay Deposit from Edo, Ogun, Ondo and Ekiti State of Nigeria for Ceramic Water Filters Production
}

\author{
Smart Adeleye Olubayode ${ }^{1,2^{*}}$, Olufiropo Samson Awokola1, Enoch Olugbenga Dare ${ }^{3}$, \\ Olubayo Timothy Olateju ${ }^{1}$ \\ ${ }^{1}$ Department of Civil Engineering, University of Agriculture, Abeokuta, Nigeria \\ ${ }^{2}$ Engineering Materials Development Institute, Akure, Nigeria \\ ${ }^{3}$ Department of Chemistry, University of Agriculture, Abeokuta, Nigeria \\ Email: *s.olubayode@yahoo.com
}

Received 18 December 2015; accepted 15 January 2016; published 18 January 2016

Copyright (C) 2016 by authors and Scientific Research Publishing Inc.

This work is licensed under the Creative Commons Attribution International License (CC BY).

http://creativecommons.org/licenses/by/4.0/

(c) $\underset{\mathrm{EY}}{\mathrm{B}}$ Open Access

\begin{abstract}
This study is designed to investigate the suitability of selected Nigeria clay deposit for clay based ceramic water filters (CWFs). Clay samples were taken from five randomly selected locations in Nigeria Namely: Okpella (Edo ${ }^{1}$ ) and Ojirami (Edo ${ }^{2}$ ) in Edo; Ikere in Ekiti state; FUTA in Ondo state and Onibode in Ogun to determine their suitability for clay based ceramic water filters (CWFs). Experimental analysis for linear shrinkage, water absorption, bulk density, compressive strength $X$-ray diffraction (XRD) and X-ray Fluorescence (XRF) was carried out on each of the clay samples. Test results reveal that all the clays contain high contents of alumina $\left(\mathrm{Al}_{2} \mathrm{O}_{3}\right)$ and silica $\left(\mathrm{SiO}_{2}\right)$ with minor contents of $\mathrm{P}_{2} \mathrm{O}_{5}, \mathrm{Fe}_{2} \mathrm{O}_{3}, \mathrm{MgO}, \mathrm{K}_{2} \mathrm{O}, \mathrm{MnO}$ and $\mathrm{TiO}_{2}$. The average crystal sizes of the clay were between 15 and $27 \mathrm{~nm}$. Lattice structure indicates that the sample is Monoclinic and Anorthic. Ceramic water filters (CWFs) were made from a mixture of clay and sawdust at different volume ratios, and processed into test samples. Water absorption, linear shrinkage and compressive strength of the clay based ceramic filters (CWFs), reveal that as the volume ratio of sawdust increases these properties decrease. Flow rate analysis indicates that Edo and Ekiti ceramic water filters (CWFs) have higher flow rates. The research indicates that Edo and Ekiti Clay with specification of some industrial clays shows that the samples can be recommended for use in clay based ceramic water filters production.
\end{abstract}

\section{Keywords}

Ceramic Water Filters, X-Ray Diffraction (XRD), X-Ray Fluorescence (XRF), Clay

\footnotetext{
"Corresponding author.
} 


\section{Introduction}

The complex nature of clay makes its study and findings an ever fresh area of interest especially to the world of science. Clay and its minerals have played major roles in anthropogenic activities. The low cost of clay and its relative abundance in nature, high sorptive/electric charge properties, plus ion exchange ability and compatibility with several materials, give it a wide range of application [1] and [2].

The basic rocks from which clays are formed are complex alumina silicates that exist in various proportions and contain varied amounts of impurities of iron, organic matters and residual minerals [3], during the weathering these become hydrolysed and the alkali and alkaline earth ions form soluble salts and are leached out. The remainder consists of hydrated alumina silicates of varying composition and structure, and free silica. It is the orientation of this predominantly silica structure that gives clay its unique plastic property.

Clay based ceramic water filters (CWFs) are usually produced by mixing of clay, sawdust (woodchips) and water [4]. Although porous CWFs have been used successfully in the field [4]-[7] for over a decade, the suitability and utilization of the vast Nigeria clay deposit cannot be over emphasized. Thus, the present study is designed to investigate the suitability of selected Nigeria clay deposit from Edo, Ogun and Ekiti States for clay based ceramic water filters (CWFs).

\section{Materials and Methods}

\subsection{Sample Preparation}

The samples were taken from five randomly selected locations in Nigeria Namely: Okpella (Edo ${ }^{1}$ ) and Ojirami $\left(E^{2}{ }^{2}\right)$ in Edo; Ikere in Ekiti state; FUTA in Ondo state and Onibode in Ogun.

The collected samples were dried in open air, after which, the samples were manually crushed into thin particles using a mortar and pestle, and then levitated using the water extraction method. The clay samples were mixed with distilled water and thoroughly stirred and allowed to hydrate for several hours and latter decanted this process is repeated until purer clay is obtained. The samples were sun dried and subsequently dried in a laboratory oven at $110^{\circ} \mathrm{C}$ for 24 hours. The resulting dried clay samples were pulverized and sieve with a digital octagon sieve shaker BS/ISO 3310 to an average particle size of $150 \mu \mathrm{m}$, and label as processed clay (PC), and sent for analysis.

\subsection{Clay Based Ceramic Filters Formation}

The clay samples were mixed with sawdust in five (5) different ratios into homogenous paste using an electronic mill, with water as the binding agent. The resulting mixture (clay, sawdust and water) was form into 3 geometrical shapes; cylindrical, flat and cubes slabs; it was there after dried in an oven (temperature of $105^{\circ} \mathrm{C}$, humidity of $40 \%$ ) for 24 hours. After drying, the samples were sintered in a muffle furnace. The firing involved pre-heating of the sample to $450^{\circ} \mathrm{C}-500^{\circ} \mathrm{C}$ (to burn off the sawdust), followed by heating to the sintering temperature of $850^{\circ} \mathrm{C}$ for six hours in the same muffle furnace.

\subsection{Materials Characterization}

\subsubsection{Determination of Linear Shrinkage}

Clay sample were made into flat bars of $12 \mathrm{~cm} \times 3 \mathrm{~cm} \times 1 \mathrm{~cm}$ was dried at room temperature for 14 days, after which the final length was measured. Total percentage shrinkage was determined using the formula;

$$
\% \text { linear shrinkage }=\frac{\text { initial length }- \text { final length }}{\text { initial length }} \times 100 \%
$$

\subsubsection{Water Absorption}

Flat bar of clay samples were first weighed using an electronic weighing balance, soaked in a bowl of water for 24 hours. Each was then removed from water, allowed to drip and the remaining was gently wiped to ensure that no water was attached to the surface and was re-weighed again. The difference in weight was then used in computing the percentage water absorption applying the formula below:

$$
\% \text { Water Absorption }=\frac{\text { soaked weight }- \text { dry weight }}{\text { dry weight }} \times 100 \%
$$




\subsubsection{Compressive Strength}

The compressive strength was determined using the Instron Universal Tester Model No: 3069, with a compressive load rate of $70 \mathrm{~N} / \mathrm{min}$.

\subsubsection{Elemental Characterization.}

The quantitative analysis of chemical components of both processed and unprocessed clay was done using EDX 3600B Energy Dispersive X-ray Fluorescence (EDXRF) spectrometer.

\subsubsection{X-Ray Diffraction Analysis}

The X-ray diffraction (XRD) was monitored using X-ray diffractometer GBC EMMA, CuKa radiation using an acceleration voltage of $25 \mathrm{kV}$ and current of $400 \mu \mathrm{A}$. The diffraction angle was scanned from $10^{\circ}$ to $65^{\circ} 2 \theta$, at a rate of $4.00^{\circ} \mathrm{min}$.

\subsubsection{Flow Rate Analysis}

Prior to the water flow experiments, the CWFs were saturated by complete submersion in a vat containing distilled water. The ceramic pot was first placed into a plastic receptacle that was fitted with a large plastic funnel. The filter and receptacle-funnel were suspended above an empty collection bucket. A known volume of distilled water was poured into the CWF, and the volume of the water that flowed into the collection bucket was measured. The flow rates were obtained by measuring the volume of water discharged from the CWFs as a function of time.

\section{Result and Discussions}

\subsection{X-Ray Diffraction Analysis}

X-Ray Diffraction Analysis the clay samples are shown in Figure 1, while the average crystal size and lattice structure parameter are shown in Table 1.

Mineralogical compositions as determined by X-ray diffraction in Figure 1, shows that kaolinite $\mathrm{Al}_{2} \mathrm{Si}_{2} \mathrm{O}_{5}(\mathrm{OH})_{4}$, as the predominant mineral content in all samples Other mineral constituents detected include

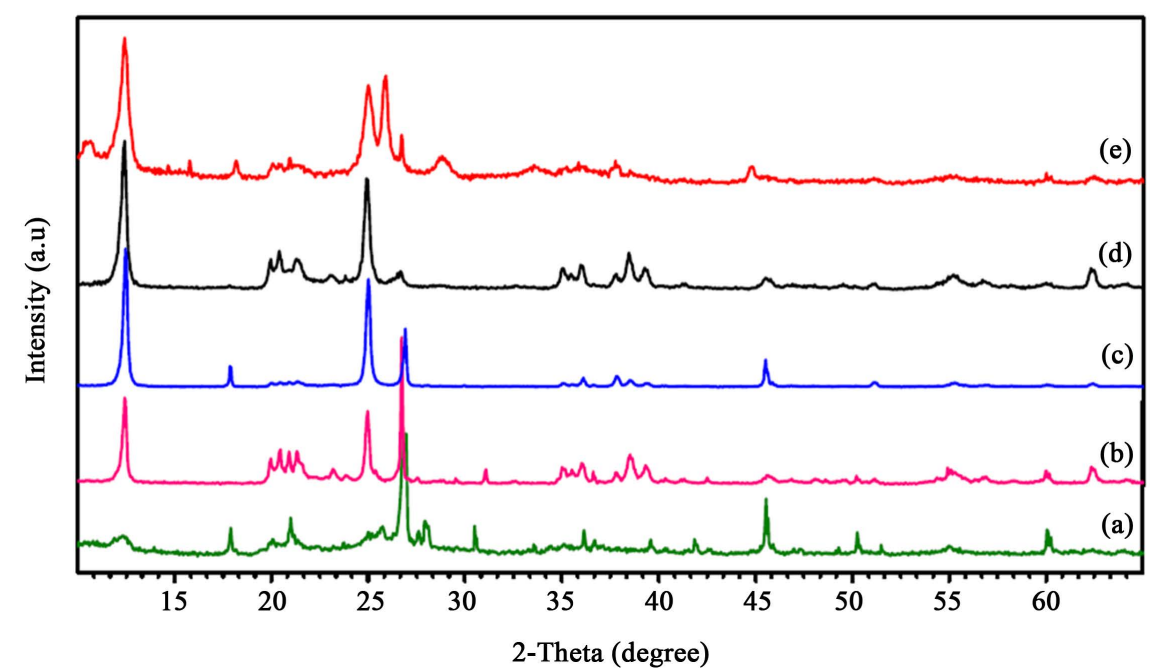

Figure 1. X-Ray diffraction of selected clays (a) Edo ${ }^{1}$, (b) Edo ${ }^{2}$, (c) Ondo, (d) Ogun, (e) Ekiti.

Table 1. Average crystal size and lattice structure parameter of clay XRD.

\begin{tabular}{ccccc}
\hline Property & Edo $^{1}$ & Ekiti & Edo $^{2}$ & Ondo $^{\text {Ogun }}$ \\
\hline Average Crystal Size (nm) & 19.95 & 27.84 & 26.57 & 15.88 \\
Lattice Structure & Monoclinic & Monoclinic & Monoclinic & Anorthic \\
\hline
\end{tabular}


free silica or quartz $\left(\mathrm{SiO}_{2}\right)$, illite $\left\{\mathrm{KAl}_{2}\left(\mathrm{Si}_{3}, \mathrm{Al}\right) \mathrm{O}_{10}(\mathrm{OH})_{2}\right\}$, The major non-clay mineral constituent in these samples were quartz. The percentage composition of quartz ranges from $9 \%$ to $21 \%$. Feldspar's $\left\{(\mathrm{K}, \mathrm{Na}) \mathrm{AlSi}_{3} \mathrm{O}_{8}\right\}$, composition in sample d, was however lower than that of other clays used in the research. According to Brown et al. [6] feldspars are the most abundant mineral group found in Earth's crust. Albite $\left(\mathrm{NaAlSi}_{3} \mathrm{O}_{8}\right)$ anchors the two main feldspar compositional series: the alkali feldspars $(\mathrm{Na}, \mathrm{K}) \mathrm{AlSi}_{3} \mathrm{O}_{8}$ and the plagioclase series $(\mathrm{Na}, \mathrm{Ca}) \mathrm{Al}(\mathrm{Si}, \mathrm{Al}) \mathrm{Si}_{2} \mathrm{O}_{8}$.

Generally, the XRD result revealed a high degree of crystalinity in all the samples. Careful investigation has reveals that all samples were composed essentially of $\mathrm{SiO}_{2}, \mathrm{Al}_{2} \mathrm{O}_{3}$, and to very limited extent of $\mathrm{K}_{2} \mathrm{O}$ and $\mathrm{Fe}_{2} \mathrm{O}_{3}$. Some other oxides were also present but in very negligible proportions. All the samples showed Kaolinite $\mathrm{Al}_{2} \mathrm{Si}_{2} \mathrm{O}_{5}(\mathrm{OH})_{4}$ as the predominant mineral content with main reflections of silicon oxide and kaolinite.

\subsection{Chemical Analysis}

The X-ray Fluorescence (XRF) results showed in Table 2 indicated that all the clays except Ekiti were siliceous in nature, having the highest number of silica present. Also the presence of Aluminum oxide of the order of between $34 \%-45 \%$ makes them to fall under the class of Alumino-Silicate refractories [8]. These values are comparable to those obtained for residual and secondary clays from other parts of Nigeria. The presence of iron in the clay samples is clearly observed although in various amounts; this has been supported by various researchers as a rule rather than exception [9]-[11].

\subsection{Physical Parameters of Raw and Blended Clay}

The ratio of clay-sawdust are shown in Table 3, while Table 4 shows test result of Bulk density, linear shrinkage, water absorption and compressive strength of both raw and blended clay.

Water absorption and Liner shrinkage results shown in Figure 2; indicate that as the volume ratio of sawdust increases the water absorption of blended clay increases, this might be due to the porosity of the ceramic filter with the addition of sawdust which is hydrophilic in nature. Ondo clay has the highest water absorption followed by Ogun, while Edo ${ }^{2}$ recorded the lowest water absorption rate.

Linear shrinkage shown in Figure 3 indicates that clay from Ogun has the lowest shrinkage, while Ekiti clay recorded has the highest shrinkage value.

Compressive strength result are shown in Figure 4, were it was seen to decrease linearly $\left(R^{2}=0.8869\right)$ with increasing porosity caused by the addition of different volume ratio of sawdust. Clay samples from Edo ${ }^{2}$ shows superior strength compare to other clay sample used for this research.

Table 2. Elemental characteristics of clay sample.

\begin{tabular}{ccccccccccc}
\hline Locations & $\mathbf{A l}_{2} \mathbf{O}_{3}$ & $\mathbf{S i O}_{2}$ & $\mathbf{P}_{2} \mathbf{O}_{5}$ & $\mathbf{S O}_{3}$ & $\mathbf{K}_{2} \mathbf{O}$ & $\mathbf{C a O}$ & $\mathbf{M n O}$ & $\mathbf{F e}_{2} \mathbf{O}_{3}$ & $\mathbf{O t h e r s}$ \\
\hline Edo & & & & & & & & & & \\
Ekiti & 4.392 & 5.683 & 0.191 & 0.403 & 1.246 & 0.271 & 0.056 & 4.939 & 1.819 \\
Edo & & 42.321 & 0.013 & 0.015 & 1.31 & 0.053 & 0.014 & 5.112 & 1.501 \\
Ondo & 38.436 & 51.338 & 0.184 & 0.451 & 2.093 & 0.284 & 0.093 & 6.472 & 0.649 \\
Ogun & 42.303 & 50.074 & 0.149 & 0.578 & 1.582 & 0.052 & 0.026 & 4.586 & 0.650 \\
\hline
\end{tabular}

Table 3. Volume ratio of clay-sawdust from different location.

\begin{tabular}{|c|c|c|c|c|c|}
\hline \multicolumn{5}{|c|}{ Locations } & \multirow{2}{*}{$\begin{array}{c}\text { Clay: Sawdust (\%) } \\
100: 0\end{array}$} \\
\hline Edo $^{1}$ & Ekiti & Edo $^{2}$ & Ogun & Ondo & \\
\hline $\operatorname{Ed}^{1}(a)$ & Ek (a) & $\operatorname{Ed}^{2}(a)$ & Og (a) & Od (a) & $70: 30$ \\
\hline $\mathrm{Ed}^{1}(\mathrm{~b})$ & Ek (b) & $\mathrm{Ed}^{2}(\mathrm{~b})$ & Og (b) & Od (b) & $65: 35$ \\
\hline $\operatorname{Ed}^{1}(\mathrm{c})$ & Ek (c) & $\mathrm{Ed}^{2}(\mathrm{c})$ & Og (c) & Od (c) & $55: 45$ \\
\hline $\operatorname{Ed}^{1}(d)$ & Ek (d) & $\mathrm{Ed}^{2}(\mathrm{~d})$ & $\mathrm{Og}(\mathrm{d})$ & $\operatorname{Od}(\mathrm{d})$ & $50: 50$ \\
\hline $\mathrm{Ed}^{1}(\mathrm{e})$ & Ek (e) & $\mathrm{Ed}^{2}(\mathrm{e})$ & Og (e) & Od (e) & $40: 60$ \\
\hline
\end{tabular}




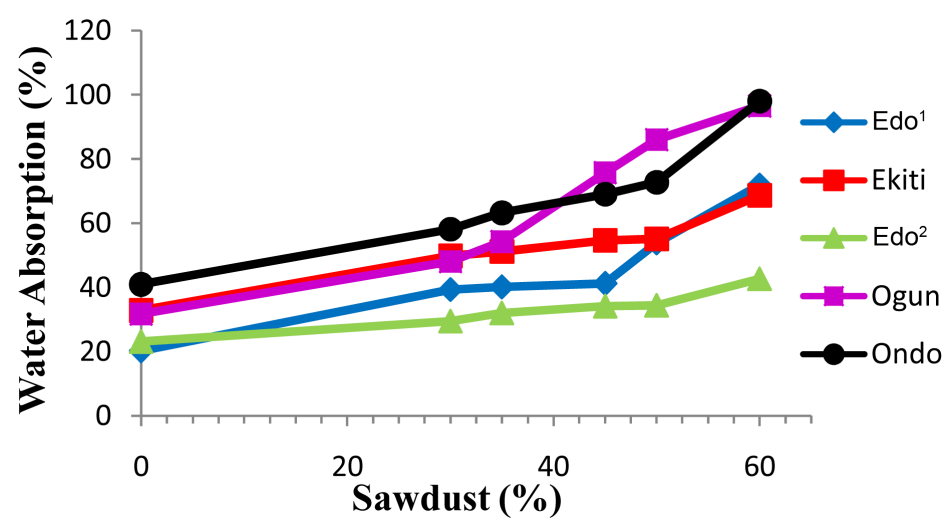

Figure 2. Variation of water absorption with sawdust volume ratio.

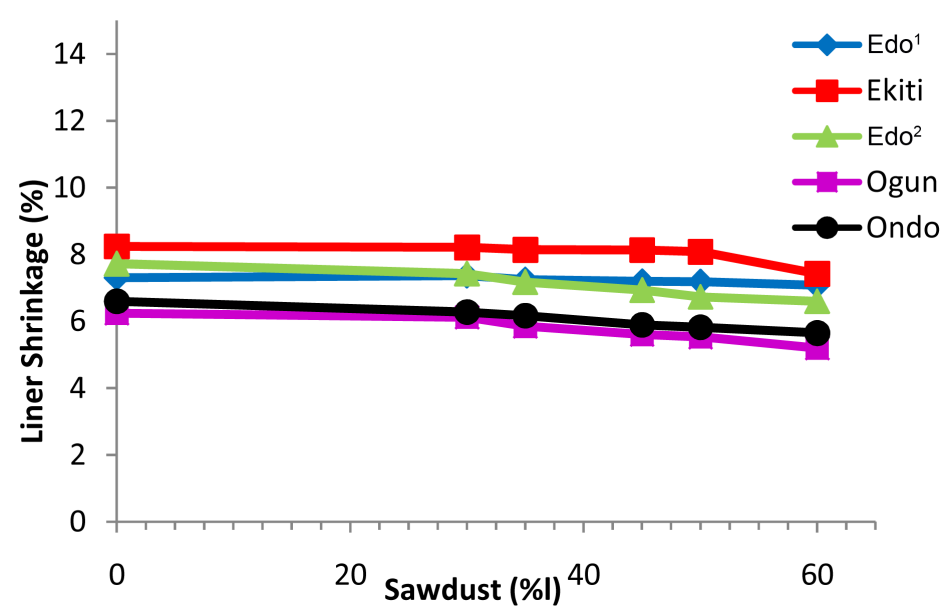

Figure 3. Variation of liner shrinkage with sawdust volume ratio.

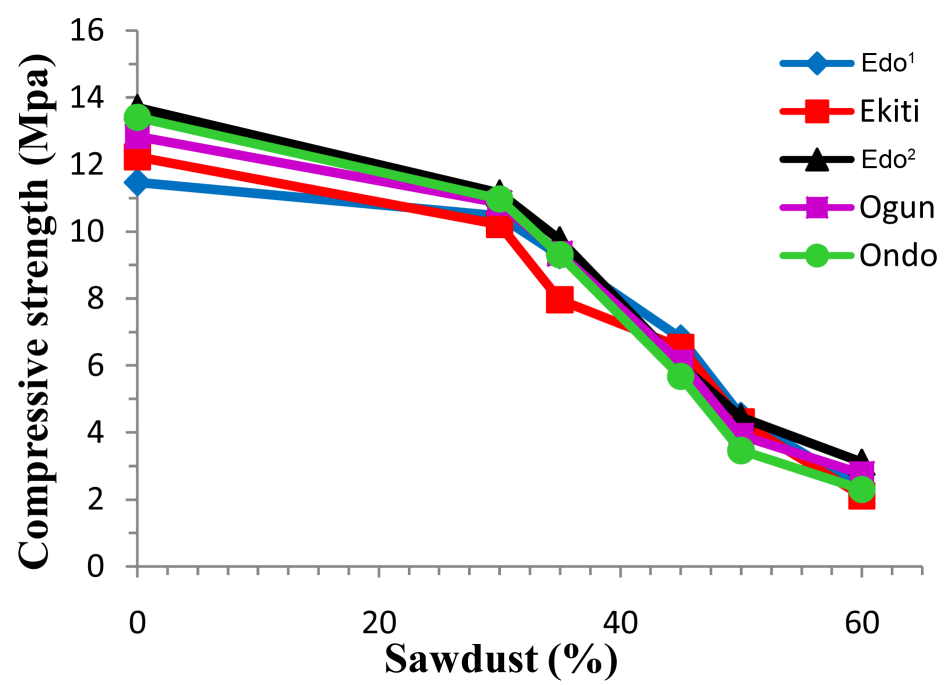

Figure 4. Variation of compressive strength with sawdust volume ratio.

From Figure 5, it was observed that, the flow rate of the clays samples increase as sawdust volume fraction increase, with clay from Lagos having the highest flow rate. However clay from Ogun has the lowest flow rate of 0.087 liters per hour. 


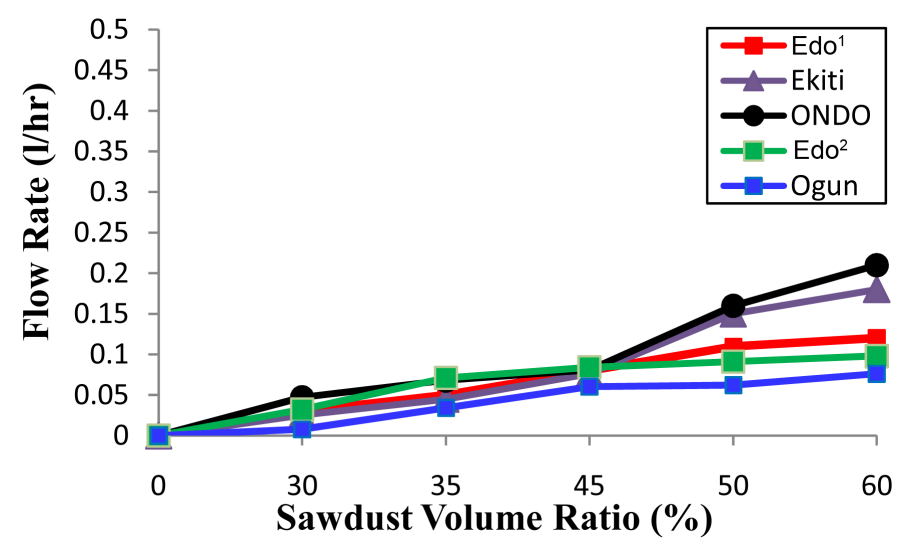

Figure 5. Variation of flow rate with sawdust volume ratio.

Table 4. Physical parameters of blended clay.

\begin{tabular}{|c|c|c|c|c|c|c|}
\hline Locations & Edo $^{1}$ & $\operatorname{Ed}^{1}(\mathrm{a})$ & $\mathrm{Ed}^{1}(\mathrm{~b})$ & $\operatorname{Ed}^{1}(\mathrm{c})$ & $\mathrm{Ed}^{1}(\mathrm{~d})$ & $\operatorname{Ed}^{1}(\mathrm{e})$ \\
\hline Water Absorption (\%) & 20.23 & 39.36 & 40.12 & 41.18 & 53.81 & 71.93 \\
\hline Liner Shrinkage (\%) & 7.3 & 7.37 & 7.24 & 7.2 & 7.18 & 7.08 \\
\hline Flow rate (L/hr) & 0.0 & 0.025 & 0.045 & 0.076 & 0.15 & 0.18 \\
\hline Compressive strength (Mpa) & 11.46 & 10.46 & 9.28 & 6.82 & 4.51 & 2.32 \\
\hline Locations & $\mathbf{E d o}^{2}$ & $\operatorname{Ed}^{2}(a)$ & $\mathrm{Ed}^{2}(\mathrm{~b})$ & $\operatorname{Ed}^{2}(c)$ & $\mathrm{Ed}^{2}(\mathrm{~d})$ & $\operatorname{Ed}^{2}(\mathrm{e})$ \\
\hline Water Absorption (\%) & 23.1 & 29.49 & 32.02 & 34.13 & 34.45 & 42.66 \\
\hline Liner Shrinkage (\%) & 7.72 & 7.43 & 7.17 & 6.93 & 6.73 & 6.6 \\
\hline Flow rate $(\mathrm{L} / \mathrm{hr})$ & 0.0 & 0.032 & 0.071 & 0.084 & 0.091 & 0.098 \\
\hline Compressive strength (Mpa) & 13.7 & 11.15 & 9.75 & 6.02 & 4.46 & 3.11 \\
\hline Locations & Ondo & $\operatorname{Od}(\mathrm{a})$ & Od(b) & $\operatorname{Od}(\mathrm{c})$ & $\operatorname{Od}(d)$ & Od(e) \\
\hline Water Absorption (\%) & 40.95 & 58.14 & 63.22 & 69 & 72.78 & 98.06 \\
\hline Liner Shrinkage (\%) & 6.6 & 6.28 & 6.17 & 5.89 & 5.82 & 5.65 \\
\hline Flow rate $(\mathrm{L} / \mathrm{hr})$ & 0.0 & 0.06 & 0.078 & 0.089 & 0.098 & 0.1 \\
\hline Compressive strength (Mpa) & 13.41 & 10.97 & 9.31 & 5.68 & 3.46 & 2.3 \\
\hline Locations & Ekiti & $\operatorname{Ek}(\mathrm{a})$ & $\mathrm{Ek}(\mathrm{b})$ & $\operatorname{Ek}(\mathrm{c})$ & $\operatorname{Ek}(d)$ & $\operatorname{Ek}(\mathrm{e})$ \\
\hline Water Absorption (\%) & 32.78 & 49.8 & 51.21 & 54.63 & 55.18 & 68.65 \\
\hline Liner Shrinkage (\%) & 8.24 & 8.21 & 8.14 & 8.13 & 8.08 & 7.42 \\
\hline Flow rate $(\mathrm{L} / \mathrm{hr})$ & 0.0 & 0.02 & 0.05 & 0.09 & 0.12 & 0.17 \\
\hline Compressive strength (Mpa) & 12.23 & 10.21 & 7.96 & 6.54 & 4.31 & 2.11 \\
\hline Locations & Ogun & $\operatorname{Og}(a)$ & $\operatorname{Og}(b)$ & $\operatorname{Og}(c)$ & $\operatorname{Og}(d)$ & $\operatorname{Og}(\mathrm{e})$ \\
\hline Water Absorption (\%) & 31.7 & 48.09 & 54.24 & 75.73 & 86.02 & 96.54 \\
\hline Liner Shrinkage (\%) & 6.24 & 6.12 & 5.85 & 5.61 & 5.53 & 5.2 \\
\hline Flow rate $(\mathrm{L} / \mathrm{hr})$ & 0.0 & 0.008 & 0.034 & 0.06 & 0.062 & 0.076 \\
\hline Compressive strength (Mpa) & 12.84 & 10.85 & 9.34 & 6.09 & 3.91 & 2.76 \\
\hline
\end{tabular}




\section{Conclusion}

Selected Nigeria clay deposit from Edo, Ogun and Ekiti states for clay based ceramic water filters (CWFs) has been characterized. Results obtained suggest that the sample contains high contents of alumina $\left(\mathrm{Al}_{2} \mathrm{O}_{3}\right)$ and silica $\left(\mathrm{SiO}_{2}\right)$ with minor contents of $\mathrm{P}_{2} \mathrm{O}_{5}, \mathrm{Fe}_{2} \mathrm{O}_{3}, \mathrm{MgO}, \mathrm{K}_{2} \mathrm{O}, \mathrm{MnO}$ and $\mathrm{TiO}_{2}$. Water absorption, linear shrinkage and compressive strength of the clay based ceramic filters reveal that as the volume ratio of sawdust increases these properties decrease. Flow rate indicates that Ondo and Ekiti blended clays have higher flow rates, while Ogun clay has poor flow rate. A comparison of all clay used in the research indicates that Ondo and Ekiti clay with specification of some industrial clays shows that the samples can be recommended for use in ceramic filter production

\section{Acknowledgements}

The contributions and assistance of the Managing Director EMDI, Engr (Dr.) Olusunle, and staff of EMDI especially, Mr. Patrick Ehi Imoisili, Miss Theresa Ezenwafor, Mr. Monday Eshiett and Mr. Femi Osho are greatly appreciated.

\section{References}

[1] Barbel, S. and Kurniawan, T.A. (2003) Low-Cost Adsorbents for Heavy Metals Uptake from Contaminated Water: A Review. Journal of Hazardous Materials, 97, 219-243. http://dx.doi.org/10.1016/S0304-3894(02)00263-7

[2] Costanzo, P.M. (2001) Baseline Studies of The Clay Minerals Society Source Clays: Introduction. Clays and Clay Mineral, 49, 372-373. http://dx.doi.org/10.1346/CCMN.2001.0490502

[3] Akinfolarin, J.F. and Awopetu, O.O. (2014) The Effect of Sawdust on the Insulating Effect of Ikere Clay as Refractory Lining. AU Journal of .Technology, 17, 143-147.

[4] Oyanedel-Craver, V.A. and Smith, J.A. (2008) Sustainable Colloidal-Silver-Impregnated Ceramic Filter for Point-ofUse Water Treatment. Environmental Science \& Technology, 42, 927-933. http://dx.doi.org/10.1021/es071268u

[5] Albert, J., Luoto, J. and Levine, D. (2010) End-User Preferences for and Performance of Competing POU Water Treatment Technologies among the Rural Poor of Kenya. Environmental Science \& Technology, 44, 4426-4432. http://dx.doi.org/10.1021/es1000566

[6] Brown, J., Proum, S. and Sobsey, M.D. (2009) Sustained Use of a Household-Scale Water Filtration Device in Rural Cambodia. Journal of Water and Health, 7, 404-412. http://dx.doi.org/10.2166/wh.2009.085

[7] Lantagne, D., Klarman, M., Mayer, A., Preston, K., Napotnik, J. and Jellison, K. (2010) Effect of Production Variables on Microbiological Removal in Locally-Produced Ceramic Filters for Household Water Treatment. International Journal of Environmental Health Research, 20, 171-187. http://dx.doi.org/10.1080/09603120903440665

[8] Folorunso D.O., Olubambi, P. and Borode, J.O. (2014) Characterization and Qualitative Analysis of Some Nigerian Clay Deposits for Rafractory Applications. IOSR Journal of Applied Chemistry, 7, 40-47. http://dx.doi.org/10.9790/5736-7914047

[9] Badraoui, M. and Bloom, P.R.(1990) Iron-Rich High-Charge Beidellite in Vertisols and Mollisols of the High Chaouia Region of Morocco. Soil Science Society of America Journal, 54, 267-274. http://dx.doi.org/10.2136/sssaj1990.03615995005400010043x

[10] Boiabid, R., Badraoui, M. and Bloom, P.R. (1991) Potassium Fixation and Charge Characteristics of Soil Clays. Soil Science Society of America Journal, 55, 1493-1498. http://dx.doi.org/10.2136/sssaj1991.03615995005500050049x

[11] Badaut, D., Decarreau, A. and Besson, G. (1992) Ferripyrophyllite and Related Fe ${ }^{3+}$-Rich 2:1 Clays in Recent Deposits of Atlantis II Deep, Red Sea. Clay Minerals, 27, 227-244. http://dx.doi.org/10.1180/claymin.1992.027.2.07 